\title{
DATA QUALITY IN TERRESTRIAL ASSEMBLAGES: PERSPECTIVES FROM VOLCANICLASTIC SEQUENCES OF THE JOHN DAY BASIN, OREGON
}

\author{
FREMD, Ted J., U.S. National Park Service, John Day Fossil Beds National Monument, \\ HCR 82, Box 126, Kimberly, OR 97848, U.S.A.
}

A wide variety of depositional environments influenced the preservation and distribution of organisms within the classic deposits of "the John Day". A composite thickness of roughly 2,500 meters of predominantly volcaniclastic strata spans over 40 million years (middle Eocene to late Miocene) during profound global paleoclimate changes and local development of a prominent rain shadow formed by the ancestral Cascade Range. A record of cooling, drying, and increased seasonality in this small basin is well-documented from a number of lines of evidence. Recent efforts to refine the ages of the tuffaceous units have been successful using single crystal laser fusion argon dating techniques (Swisher and others, unpublished data), offering excellent biostratigraphic resolution of first and last appearance data assuming high quality, relatively unbiased samples.

Dozens of assemblages from hundreds of localities in a relatively small geographic area have been examined in detail during the course of long term studies on the area, resulting in a number of monographs on the most spectacular floras and vertebrate fossils. None of the published studies, however, have included detailed taphonomic analyses of these major accumulations, much less the wealth of data in the intervening, poorly studied sites. In this contribution, six of the most significant assemblages are commented on and contrasted with data from the intervening units.

Within the Clarno Formation, the middle Eocene (Bridgerian) "Nut Beds" and associated fauna were deposited in a series of lahar runouts and probably reflects considerable mixture by fluvial processes. Varied floral components (seeds, pollen, leaves, stems, etc.) of a taxonomically very diverse paratropical assemblage are mixed with fragmentary vertebrate fossils deposited in a relatively short time frame. A thick sequence of fossiliferous paleosols and lahars is capped by the late Eocene (Duchesnean) Hancock Mammal Quarry, containing a "bone-bed" accumulation of vertebrate fossils and a small flora.

The early Oligocene John Day Formation's "Bridge Creek flora" consists of dozens of widely separated localities, each containing different species compositions and matrices varying from fine grained lacustrine shales to tuffaceous silty inceptisols. Recent work on the type area points out the need for detailed sampling at each site with fine stratigraphic resolution, as at least three different floral assemblages have been lumped together in previous paleoecologic studies.

The late Oligocene to early Miocene (Arikareean) "John Day Faunas" are world-renowned. This 10 my sequence of highly variable assemb lages reflects shifting patterns of bone accumulations through time, with a bewildering variety of taphonomic histories.

The middle Miocene (Barstovian) Mascall faunal localities are spatially and temporally scattered throughout over 300 meters of predominantly bioturbated tuffaceous horizons, and are often directly associated with vitric tuffs. The floras (and aquatic organisms) accumulated in diatomaceous lacustrine sequences. The late Miocene (Hemphillian) Rattlesnake fauna consists of dispersed deposits of large bone fragments and occasional microvertebrate sites in fanglomerates.

These differing taphonomic settings result in variable data reliability that must be considered in high-resolution biostratigraphy, paleoclimatic studies, and quantitative paleoecology. 